\title{
ESTIMATING THE GENETIC PARAMETERS OF YIELD AND YIELD COMPONENT TRAITS IN SQUASH (Cucurbita pepo,
}

L.)

\author{
Abd El-Hadi, A. H. ; K. A. Zaied and Eman A. Abd El-Raziq. \\ Dept. of Genetics, Faculty of Agric. Mansoura University, Egypt.
}

\begin{abstract}
The main objective of this investigation was to determine the genetic parameters, heritability in both broad and narrow senses, combining abilities and correlation for yield and yield component traits in squash (Cucurbita pepo, L.). For this purpose, five squash varieties were used .These varieties were: Eskandrani $\left(P_{1}\right)$; Zucchino tondo di piacenza $\left(P_{2}\right)$; Black beouty $\left(P_{3}\right)$; Zucchino romanesco $\left(P_{4}\right)$ and Coppi $\left(P_{5}\right)$. During the summer season of 2011, acomplete diallel crosses mating design was made to evaluate the performances of the $20 \mathrm{~F}_{1}$ hybrids including the reciprocal will their five parental varieties in afield trial at the Experimental Station, Faculty of Agriculture, Mansoura University.

Data were recorded on the following traits, number of fruitsper plant (No.F./P.), fruits yield per plant (F.Y./P.Kg), fruit length (F.L.cm), fruit diameter (F.D.cm) and fruit shape index (F.Sh.I).

The results indicated that the mean squares for all genotypes were highly significant for all yield and yield component traits.

The results of means showed that Eskandrani $\left(P_{1}\right)$ was the highest parent for Number of fruits per plant No.F./P. the parental variety Zucchino romanesco $\left(P_{4}\right)$ was the highest variety for F.L.cm and F.Sh.I. However, the highest $F_{1}$ hybrid for fruit yield per plant was Eskandrani $\left(P_{1}\right) \times$ Zucchino tondo di piacenza $\left(P_{2}\right)$ with the mean value of $11.24 \mathrm{~kg}$. Whereas, the highest $F_{1 r}$ hybrid was Zucchino romanesco $\left(P_{4}\right) \times$ Eskandrani $\left(P_{1}\right)$ with the mean value of $10.51 \mathrm{~kg}$.

The results revealed that the GCA effects (gi) were highly significant for the two parents: Eskandrani $\left(P_{1}\right)$ and Zucchino romanesco $\left(P_{4}\right)$ for F.L.cm, F.D.cm and F.Sh.I traits. At the same time, the results also revealed that the GCA effects were highly significant for the parents: Zucchino tondo di Piacenza $\left(P_{2}\right)$ for F.L.cm and F.D.cm; Black beouty $\left(P_{3}\right)$ for F.D.cm and F.Sh.I and Coppi $\left(P_{5}\right)$ for F.Sh.I.

The results indicated the importance of both (GCA) and (SCA) combining abilities. General combining abilities (GCA) were larger than specific combining abilities (SCA) for all yield and yield component traits except fruits yield per plant (F.Y./P.Kg). The estimates of heritability in broad sense $\left(h^{2}{ }_{b}\right)$ were larger in magnitudes than those of narrow sense $\left(h^{2}{ }_{n}\right)$ for all studied traits. The values of heritabilities in broad sense ranged from 0.513 to 0.894 for yield and yield component traits.
\end{abstract}

\section{INTRODUCTION}

Kasrawi (1994) and Ahmed et al., (2003) investigated the heterosis effects using a set of diallel crosses among five summer squash lines over two seasons. The results revealed that the heterosis over the mid-parent values were present for all the yield traits. Similarly, Li-Jian-wu et al., (1995). observed positive heterosis values in cucumber for total yield; early yield; fruit number and average fruit weight. Negative heterosis was obtained for vine length trait. Yield and yield components were affected by fruit number and average fruit weight. 
Abd El-Hadi, A. H. et al.

Firpo et al., (1998). reported high heterosis for total fruit number and precocious fruit number in the crosses between inbred lines derived from a summer squash(C. pepo) population. Also they concluded that inbreeding and crossing methods could be a useful tool in increasing the population means for yield traits through developing hybrid or a synthetic variety. However, in pumpkins, Mohanty (2000). evaluated a set of diallel crosses among eight lines and investigated the heterotic effects for yield components. The results revealed that exploitation of heterosis appeared to be limited. Ten crosses showed highly significant heterosis values relative to their best parent for yield trait. In the same time, In sweet melon, Abd El-Hadi et al., (2001). studied heterosis for fruit trait and found that the means of the $F_{1}$ hybrids significantly exceeded their mid-parents. Also, El-Diasty et al., (2002). evaluated $16 F_{1}$ hybrids and their eight parents using $(4 \times 4)$ factorial mating design. The results indicated that the highest value of heterosis from the better parent was $41.05 \%$ for number of male flowers per plant. While, heterosis value of $F_{1}$ versus the better parent was $19.68 \%$ for number of fruits per plant. In watermelon, Souza et al., (2005) found that most hybrids showed positive heterosis for most studied quality traits in relation to the parental means and the standard cultivar.

Through the estimatation of heterosis values from the mid-parent and the better parent for yield and its component traits, it was observed that the average means of the $F_{1}$ hybrids significantly exceeded the mid-parent for most studied yield traits. However, Ghobary and Ibrahim., (2010) found that the average fruit weight was increased from $101.9(\mathrm{~g})$ in the base population $\left(P_{0}\right)$ to $114.3(\mathrm{~g})$ in the $\left(P_{3}\right)$ population. This increment was estimated by 13.4 $\%$. Average numbers of total fruits and marketable fruits per plant were increased from 6.0 and 5.5 fruits per plant in the $\mathrm{P}_{0}$ population to 8.1 and 7.6 fruits per plant in the $P_{3}$ population, respectively. Such increase was estimated as $35 \%$ and $38.2 \%$, respectively. Average weights of total fruits and marketable fruits per plant were increased from 0.640 and $0.579(\mathrm{~kg})$ in the $P_{0}$ to 0.927 and $0.868(\mathrm{~kg})$ in the $P_{3}$ population, respectively.

Lopez-Anido et al., (1998) and Abd El-Hadi et al., (2005). found significant effects for both GCA and SCA for early and total yield per plant in squash. In this respect, Hatem et al., (2009). found that GCA was greater than SCA for early and total yield in melon, suggesting that additive genetic variance was more important than non-additive one. Similarly, Ana and Staub (2002) studied combining ability of yield and its components in cucumber and evaluated six $F_{1}$ hybrids for fruit number and length/ diameter ratio. They found that combining ability was significantly influenced from year to year for most traits. General combining ability was significant for all traits in each year, but specific combining ability was only significant for fruit number. In the same time, Kamooh (2002) studied five parental lines and their ten possible hybrids and indicated that general or specific combining ability, contributed highly significant differences and seemed to be responsible for the effects noticed among the single crosses. The parental line $P_{3}$ appeared to be the highest for total yield productivity, but did not differ significantly for $\mathrm{P}_{5}$ and $\mathrm{P}_{4}$. 
Concerning the GCA, the $P_{3}$ showed highest GCA followed by $P_{5}$ and $P_{4}$ without any significant differences.

El-Shimi et al., (2003) in melon, showed that genetic variances were considerably larger than those of environmental variances for all studied traits. In addition, dominance genetic variances were larger than additive genetic variance for all studied traits except for number of fruits per plant and average fruit weight. On the other hand, Abd El-Hadi et al., (2004) showed that general combining ability (GCA) were larger than their corresponding estimates of specific combining ability (SCA) for all studies traits. They showed that the non-additive genetic variances including dominance $\left(O^{2} D\right)$ were the most important source of genetic variances. Additive genetic variances $\left(0^{2} A\right)$ also were very important. Reciprocal effects $\left(o^{2} r\right)$ were presented for all studied traits, but their estimates were smaller than the additive $\left(O^{2} A\right)$ and non-additive genetic variance including dominance $\left(O^{2} D\right)$. On the other hand, in squash Ahmed et al., (2003) found that the tester Whitaker is a good combiner for yield as shown by its significant positive GCA estimate, while Eskandarany showed a significant negative GCA estimate. Also, Shamil and Wiam (2011) showed that general combining ability in squash was significant for diameter, weight and total yield/plant. The reciprocal effect was significant for all studied trait except number of fruits/plant.

Abd El-Hadi et al., (2001) studied the heritability in $F_{1}$ hybrids among new selected inbred lines of sweet melon (Cucumis melo ver. aegypttiacus, L.). The heritabilities for fruit weight, fruit length and fruit diameter were 95.70; 98.60 and $82.12 \%$ for broad sense and $26.40,82.05$ and $96.40 \%$ for narrow sense, respectively. However, in watermelon, El-Mighawry et al., (2001 indicated the heritability estimate in narrow sense was moderate for fruit shape index of about 0.524 and it was low for fruit length 0.23 .

Karuppaiah et al., (2002) found that when heritability and genetic advance were considered together, number of female flowers per plant, yield per plant, number of fruits per plant and flesh thickness recorded high values of both. On the other hand, in melon, El-Shimi et al., (2003) estimated heritability in broad sense and found it be considerably high for number of fruits plant; fruit yield plant; total yield; average fruit weight and flesh thickness. It was higher in magnitudes than the estimates in narrow sense for these traits. However, Sadek (2003) in squash, showed that heritability in broad sense was larger in magnitude than corresponding value in narrow sense for all studied traits. The highest value in broad sense was $97.64 \%$ for fruit diameter, while in narrow sense it was $87.93 \%$ for the same trait.

Abd El-Hadi et al., (2004) in squash, found that heritability in broad sense were larger than their corresponding values in narrow sense. The estimate values of heritability in narrow sense were ranged form 0.00 to $60.38 \%$ for first picking date and fruit shape index in $F_{1}$ hybrids while, ranged from 0.00 to $67.50 \%$ for fruit weight and fruit length from $F_{2}$ generations,recpectively. Similarly, Abd El-Salam et al., (2010) and Kumar and Wehner (2011) found that broad sense heritability was high than narrow sense but it was moderate for yield / feddan and fruit diameter. Also, Jahan et al., (2012) found that high heritability was coupled with high genetic 
Abd El-Hadi, A. H. et al.

advance for number of fruits per plant, individual fruit weight and fruit yield which suggested that improvement would be effective through phenotypic selection.

\section{MATERIALS AND METHODS}

The genetic materials used in the present investigation included five squash varieties belong to the species ( Cucurbita pepo, L.).This varieties included: Eskandrani $\left(\mathrm{P}_{1}\right)$; Zucchino tondo di piacenza $\left(\mathrm{P}_{2}\right)$; Black beouty $\left(P_{3}\right)$; Zucchino romanesco $\left(P_{4}\right)$ and Coppi $\left(P_{5}\right)$.

During the summer season of 2010, seeds of these varieties were cultivated at the Experimental Station, Faculty of Agriculture, Mansoura University. At the flowering time all single crosses including reciprocals were made among these five parental varieties according to a complete diallel crosses mating design to produce $10 F_{1}$ hybrids and their $10 F_{1}$ reciprocals. In addition, the five parental varieties were also self pollinated to obtain enough seeds from each variety.

In the growing season of 2011, the genetic materials resulted were evaluated in afield trial at the Experimental Station, Faculty of Agriculture, Mansoura University. The experimental design used was the Randomized Complete Blocks Design with three replications. All genotypes were randomly distributed in each block. Each replication consisted of 25 plots (five parental varieties, their $10 \mathrm{~F}_{1}$ hybrids and $10 \mathrm{~F}_{1}$ reciprocal hybrids). The plot or the experimental unit was one ridge $5.0 \mathrm{~m}$. long and $1.0 \mathrm{~m}$. wide. The distance between hills was $0.5 \mathrm{~m}$. with each ridge contained 10 hills. Seeds were planted at the rate of 4 seeds per hill. After full germination plants were thinned to one plant per hill. Land preparation, fertilizer appliications and other field practices for squash crop were done according to the recommendations of the Egyptian Ministry of Agriculture.

Data were recorded on the following traits, fruits yield per plant (F.Y./P.Kg), fruit length (F.L.cm), fruit diameter (F.D.cm) and fruit shape index (F.Sh.I).

Differences among genotypic means for all studied traits were tested for significance using F-test according to Steel and Torrie (1960). The form of the analysis of variance and the expectation of mean squares are presented in Tables 1. The tests of significance among the differences of genotypic means were made using the least significant difference method LSD at both $5 \%$ or $1 \%$ levels.

Table 1: Form of the analysis of variance and the expectations of mean squares for all genotypes.

\begin{tabular}{|c|c|c|c|}
\hline S.V. & d.f. & M.S. & E.M.S. \\
\hline Replications & $\mathrm{k}-1$ & & $\delta^{2} e+\mathrm{g} \delta^{2} k$ \\
\hline Genotypes & $\mathrm{g}-1$ & $\mathrm{M}_{2}$ & $\delta^{2} e+\mathrm{r} \delta^{2} g$ \\
\hline Error & $(\mathrm{k}-1)(\mathrm{g}-1)$ & $\mathrm{M}_{1}$ & $\delta^{2} e$ \\
\hline
\end{tabular}


Where:-

$\mathrm{k}$ : is the number of replications.

$\mathrm{g}$ : is the number of genotypes.

$M_{1}$ : is the error mean square.

$\mathrm{M} 2$ : is the genotypes mean square.

$\delta^{2} e:$ is the error variance.

$\delta^{2} g$ : is the variance of genotypes.

$\delta^{2} \mathrm{k}:$ is

the variance of replications.

The analysis of the diallel crosses mating design were made on the $10 \mathrm{~F}_{1}$ and the $10 \mathrm{~F}_{1 \mathrm{r}}$ hybrids using the methods described by Griffings III 1956 and later on out lined by sing and chaudary (1985). The form of the analysis of variance was as presented in Table 2.

Table 2: Form of the analysis of combining abilities and the expectations of mean squares.

\begin{tabular}{|c|c|c|c|}
\hline S.V. & d.f. & M.S. & E.M.S. \\
\hline Reps & $\mathrm{k}-1$ & & \\
\hline Crosses & $\mathrm{p}(\mathrm{p}-1)-1$ & & \\
\hline G.C.A. & $\mathrm{p}-1$ & $\mathrm{Mg}$ & $\delta^{2} e+2 \mathrm{k} \delta^{2} r+2 \mathrm{k} \delta^{2} s+2 r(p-2) \delta^{2} g$ \\
\hline S.C.A. & $\mathrm{p}(\mathrm{p}-3) / 2$ & $\mathrm{Ms}$ & $\delta^{2} e+2 \mathrm{k} \delta^{2} \mathrm{r}+2 \mathrm{k} \delta^{2} s+\delta^{2} s$ \\
\hline Rec. & $\begin{array}{c}\mathrm{p}(\mathrm{p}-1) / 2 \\
\text { Error }\end{array}$ & $\mathrm{Mr}$ & $\delta^{2} \mathrm{e}+2 \mathrm{k} \delta^{2} \mathrm{r}$ \\
\hline$(\mathrm{k}-1)(\mathrm{P}(\mathrm{P}-$ & $\mathrm{Me}$ & $\delta^{2} \mathrm{e}$ \\
\hline
\end{tabular}

Where:-

$\mathrm{K}, \mathrm{P}$ : are number of replications, parents and crosses, respectively.

$\delta^{2} \mathrm{~g}$ : is the variance of general combining ability.

$\delta^{2} \mathrm{~s}$ : is the variance of specific combining ability.

$\delta^{2} r$ : is the variance of reciprocal effects.

$\delta^{2} \mathrm{e}:$ is the error variance.

$\mathrm{Me} ; \mathrm{Mr} ; \mathrm{Ms}$ and $\mathrm{Mg}$ are the respective mean squares of error; rec; S.C.A. and G.C.A, respectively.

\section{RESULTS AND DISCUSSION}

The mean performances of five parental varieties, their $F_{1}$ and $F_{1} r$ hybrids for all studied traits are presented in Table 3. 
Abd El-Hadi, A. H. et al.

The mean values of the five parental varieties showed that $P_{1}$ was the highest parent for No.F./P. The parental variety $\mathrm{P}_{4}$ was the highest variety for F.L.cm and F.Sh.I. While, the two parental varieties $P_{5}$ and $P_{2}$ were the highest parents for F.Y./P.Kg and F.D.cm, respectively. In the same time, $\mathrm{P}_{2}$ was the lowest parent for F.Y./P.Kg, F.L.cm and F.Sh.I. While, the parental variety $\mathrm{P}_{4}$ was the lowest for F.D.cm.

The results of the analysis of variance and mean squares for yield and yield component traits for all genotypes are presented in Table 4.

The results indicated that the mean squares for all genotypes were highly significant for all yield and yield component traits. These results indicated the presence of large variations among these five parents and their $F_{1,1 r}$ hybrids for yield and yield component traits.

The results indicated that the highest $F_{1}$ hybrid for fruit yield per plant was $P_{1} \times P_{2}$ with the mean of $11.24 \mathrm{~kg}$. Whereas, the highest $F_{1 r}$ hybrid was $P_{4} \times$ $P_{1}$ with the mean of $10.51 \mathrm{~kg}$. On the other hand, $F_{1}$ hybrid $P_{1} \times P_{4}$ was the lowest for this trait with a mean of $8.828 \mathrm{~kg}$., while, $\mathrm{P}_{4} \times \mathrm{P}_{2} \mathrm{~F}_{1 \mathrm{r}}$ hybrid was the lowest with mean of $9.214 \mathrm{~kg}$.

In general, the means of $F_{1}$ hybrids ranged from 10.13 to 14.20 fruits; 8.828 to $11.24 \mathrm{~kg} ; 8.577$ to $13.493 \mathrm{~cm} ; 28.48$ to $43.63 \mathrm{~cm}$ and 0.207 to 0.493 for No.F./P.; F.Y./P.Kg; F.L.cm; F.D.cm and F.Sh.I, respectively. On the other hand, the mean values of the $F_{1 r}$ hybrids ranged from 10.86 to 15.16 fruits; 9.214 to $10.51 \mathrm{~kg} ; 9.477$ to $14.72 \mathrm{~cm} ; 19.49$ to $45.10 \mathrm{~cm}$ and 0.217 to 0.53 for the same traits, respectively.

These results were in agreement with the results obtained by Sadek (2003) and Abd El-Hadi et al., (2005).

The analysis of variance and mean squares of general and specific combining abilities for all studied traits are presented in Table 5.

The results revealed that the mean squares of the genotypes were highly significant for F.L.cm, F.D.cm and F.Sh.I., while, F.Y./P.Kg was insignificant. The mean squares due to general combining ability were highly significant for No.F./P.; F.L.cm; F.D.cm and F.Sh.I. This indicated that additive genetic variance was more important in the inheritance of these traits.

The values of GCA mean squares were higher than those of SCA means for F.L.cm, F.D.cm and F.Sh.I. indicating that additive genetic variance was more important in the inheritance of these traits. On the other hand, the values of SCA mean squares were larger than those of GCA for F.Y./P.Kg. This indicated that non- additive genetic variance was more important in the inheritance of this trait.

The magnitudes of GCA and SCA mean squares were equal for No.F./P. trait showing that both of them were more important in the inheritance of this trait.

These results were in agreement with the results obtained by Abd ElHadi et al., (2004). 
Table 3 : The mean performances of five parental varieties, their $F_{1}$ and $F_{1} r$ hybrids for yield and yield component traits in 2011 growing season.

\begin{tabular}{|c|c|c|c|c|c|}
\hline Genotypes & No.F./P. & F.Y./P.Kg & F.L.cm & F.D.cm & F.Sh.l. \\
\hline $\mathbf{P}_{1}$ & 10.73 & 9.737 & 13.403 & 28.85 & 0.477 \\
\hline $\mathbf{P}_{2}$ & 8.70 & 8.956 & 7.317 & 47.13 & 0.157 \\
\hline $\mathbf{P}_{3}$ & 10.30 & 9.422 & 12.56 & 29.21 & 0.433 \\
\hline $\mathbf{P}_{4}$ & 10.70 & 9.420 & 14.833 & 26.11 & 0.563 \\
\hline$P_{5}$ & 6.80 & 9.861 & 12.6 & 35.68 & 0.377 \\
\hline$P_{1} \times P_{2}$ & 10.13 & 11.24 & 12.97 & 29.20 & 0.46 \\
\hline$P_{2} \times P_{1}$ & 11.20 & 9.913 & 11.387 & 33.25 & 0.31 \\
\hline $\mathbf{P}_{1} \times \mathbf{P}_{3}$ & 10.16 & 9.408 & 12.153 & 29.00 & 0.463 \\
\hline$P_{3} \times P_{1}$ & 15.16 & 9.652 & 13.463 & 29.30 & 0.443 \\
\hline$P_{1} \times P_{4}$ & 14.20 & 8.828 & 11.793 & 29.76 & 0.437 \\
\hline $\mathbf{P}_{4} \times \mathbf{P}_{1}$ & 12.40 & 10.51 & 14.72 & 27.71 & 0.53 \\
\hline$P_{1} \times P_{5}$ & 12.50 & 10.43 & 10.96 & 32.85 & 0.363 \\
\hline$P_{5} \times P_{1}$ & 10.86 & 9.539 & 13.487 & 31.58 & 0.44 \\
\hline $\mathbf{P}_{2} \times \mathbf{P}_{3}$ & 10.46 & 10.97 & 9.127 & 35.26 & 0.29 \\
\hline $\mathbf{P}_{3} \times \mathbf{P}_{2}$ & 15.03 & 9.904 & 9.477 & 45.10 & 0.217 \\
\hline$P_{2} \times P_{4}$ & 12.60 & 9.349 & 9.003 & 39.20 & 0.253 \\
\hline$P_{4} \times P_{2}$ & 13.667 & 9.214 & 10.437 & 36.76 & 0.337 \\
\hline$P_{2} \times P_{5}$ & 10.933 & 10.84 & 8.577 & 43.63 & 0.207 \\
\hline$P_{5} \times P_{2}$ & 10.967 & 10.09 & 9.577 & 35.43 & 0.277 \\
\hline $\mathbf{P}_{3} \times \mathbf{P}_{4}$ & 13.367 & 9.608 & 13.493 & 28.48 & 0.493 \\
\hline $\mathbf{P}_{4} \times \mathbf{P}_{3}$ & 13.333 & 10.07 & 11.833 & 19.49 & 0.427 \\
\hline$P_{3} \times P_{5}$ & 13.767 & 10.05 & 12.687 & 28.65 & 0.447 \\
\hline$P_{5} \times P_{3}$ & 13.067 & 9.938 & 12.187 & 33.98 & 0.367 \\
\hline $\mathbf{P}_{5} \times \mathbf{P}_{4}$ & 13.433 & 9.739 & 13.01 & 29.75 & 0.443 \\
\hline$P_{4} \times P_{5}$ & 11.6 & 10.44 & 11.037 & 28.41 & 0.397 \\
\hline L.S.D 0.05 & 1.762 & 13.31 & 1.338 & 5.949 & 0.052 \\
\hline L.S.D 0.01 & 2.351 & 17.76 & 1.785 & 7.936 & 0.069 \\
\hline
\end{tabular}

Table 4 : Analysis of variance and mean squares for yield and yield component traits in 2011 growing season.

\begin{tabular}{|c|c|c|c|c|c|c|}
\hline S.V. & d.f & No.F./P & F.Y./P.Kg & F.L.cm & F.D.cm & F.Sh.I \\
& & & & & & \\
\hline Replications & 2 & 0.255 & 19.076 & 2.247 & 17.298 & 0.005 \\
\hline Genotypes & 24 & $11.82^{* \star}$ & $108.97^{* \star}$ & $11.583^{\star *}$ & $117.87^{* *}$ & $0.033^{* *}$ \\
\hline Error & 48 & 1.152 & 65.73 & 0.664 & 13.13 & 0.001 \\
\hline
\end{tabular}

${ }^{*}$ and $^{\star \star}$ Significant at 0.05 and 0.01 levels of probability, respectively. 
Abd El-Hadi, A. H. et al.

Table 5 : Analysis of variance and mean squares for general (GCA) and specific (SCA) combining ability for Yield and yield component traits.

\begin{tabular}{|c|c|c|c|c|c|}
\hline d.f. & No.F./P. & F.Y./P.Kg & F.L.cm & F.D.cm & F.Sh.I. \\
\hline 24 & $11.821^{\star *}$ & 108.967 & $11.583^{\star *}$ & $118.337^{* *}$ & $0.033^{\star *}$ \\
\hline 4 & $4.894^{\star *}$ & 23.407 & $16.536^{\star *}$ & $165.95^{\star *}$ & $0.053^{\star *}$ \\
\hline 10 & $4.605^{\star *}$ & 38.322 & $1.190^{\star *}$ & $13.00^{\star *}$ & $0.002^{* \star}$ \\
\hline 10 & $2.895^{\star *}$ & 39.488 & $1.462^{\star *}$ & $15.290^{\star *}$ & $0.003^{\star *}$ \\
\hline 48 & 0.384 & 21.911 & 0.221 & 4.487 & 0.001 \\
\hline
\end{tabular}

*and ${ }^{\star \star}$ Significant at 0.05 and 0.01 levels of probability, respectively.

The relative magnitudes of different genetic parameters and heritability for yield and yield component trait are presented in Table 6 .

The results showed that both additive $\left(\sigma^{2}{ }_{A}\right)$ and non-additive genetic variances including dominance $\left(\sigma^{2}\right)$ were positive and highly significant for yield and its component traits except for F.Y./P.Kg which was insignificant. The results indicated that these two genetic variances play a major role in the genetic expression of yield and yield component traits. The magnitudes of additive genetic variance which was larger than the dominance genetic variance for F.L.cm, F.D.cm and F.Sh.I. traits suggested that additive genetic variance was predominat in the inheritance of these traits. The reciprocal variances were smaller than the additive genetic variances for F.L.cm, F.D.cm and F.Sh.I. traits. In general, the heritability in broad sense $\left(h^{2}\right)$ were high and larger than their corresponding values of heritability in narrow sense $\left(\mathrm{h}_{\mathrm{n}}^{2}\right)$ for all studied traits. Heritability in broad sense ranged from 0.241 to 0.943 for F.Y./P.Kg and F.L.cm, respectively . In the same time, the highest value of $h^{2}{ }_{n}$ was 0.865 for F.Sh.l.

These results were also in agreement with the results obtained by AbdEISalam et al., (2010) and Kumar et al., (2011).

General combining ability effects of the five parental varieties for all studied traits are presented in Table 7.

The results revealed that the GCA effects (gi) were showed highly significant and desieable for parent $\mathrm{P}_{1}$ and $\mathrm{P}_{4}$ for F.L.cm and F.Sh.I traits. At the same time, the results revealed that the GCA effects were significant for parent $P_{2}$ for F.D.cm and parent $P_{3}$ for F.Sh.I .

These results were also in agreement with the results obtained by Hatem et al., (2009), Souza et al., . (2002) and Abd El-Hadi et al. (2004)

Specific combining ability effects of the five parental varieties for all studied traits are presented in Table 8.

For No.F./P. the $F_{1}$ hybrids $P_{3} X p_{5}$ and $P_{4} X p_{5}$ gave the highest values of specific combining ability effect of 1.691 and 0.917 , respectively.

The $F_{1}$ hybrid $P_{1} \times P_{2}$ gave the highest positive and significant value of (6.199) For F.Y./P.Kg. At the same time, the $F_{1 r}$ hybrid $P_{2} \times P_{1}$ gave the highest positive and significant value of $(6.653)$ for the same trait.

For F.L.cm the $F_{1}$ hybrid $P_{1} \times P_{2}$ and $F_{1 r}$ hybrid $P_{4} \times P_{5}$ gave highly significant positive values. However, the $F_{1 r}$ hybrid $P_{4} \times P_{1}$ gave highly significant negative value. The $F_{1}$ hybrid $P_{1} \times P_{2}$ gave the highly significant 
negative value of -5.475 for F.D.cm. Out the $F_{1 r}$ hybrids $P_{5} \times P_{2}$ and $P_{4} \times P_{3}$ gave the highly significant positive values for the same trait.

For F.Sh.l. the $F_{1}$ hybrid $P_{1} \times P_{2}$ gave the highly significant positive value of (0.063). While, the $F_{1}$ hybrids $P_{2} \times P_{1}$ and $P_{5} \times P_{3}$ gave highly significant positive values of 0.075 and 0.040 for the same trait. The $F_{1 r}$ hybrid $\mathrm{P}_{4} \times \mathrm{P}_{1}$ and $\mathrm{P}_{4} \times \mathrm{P}_{2}$ gave the highly significant negative values -0.047 and 0.041 for the same trait.

Table 6: The relative magnitudes of different genetic parameters and heritability for yield and yield component trait .

\begin{tabular}{|c|c|c|c|c|}
\hline $\begin{array}{c}\text { Genetic } \\
\text { parameters and } \\
\text { heritability }\end{array}$ & F.Y./P.kg & F.L.cm & F.D.cm & F.Sh.I. \\
\hline $\boldsymbol{\sigma}^{2} \mathbf{A}$ & -2.827 & 3.078 & 30.67 & 0.010 \\
\hline $\boldsymbol{\sigma}^{2} \mathbf{D}$ & 9.768 & 0.577 & 5.067 & 0.0006 \\
\hline $\boldsymbol{\sigma}^{2} \mathbf{r}$ & 8.789 & 0.621 & 5.401 & 0.001 \\
\hline $\boldsymbol{\sigma}^{2} \mathrm{E}$ & 21.91 & 0.221 & 4.489 & 0.000 \\
\hline $\mathbf{H}^{2}{ }_{\mathbf{b}} \%$ & 0.241 & 0.943 & 0.888 & 0.915 \\
\hline $\mathbf{H}^{2}$ ${ }^{2} \%$ & 0.000 & 0.794 & 0.762 & 0.865 \\
\hline
\end{tabular}

Note: Negative values were considered equal to zero during the calculation of heritability in broad and narrow se

Table 7 : General combining ability effects $\left(g_{i}\right)$ of the five parents for yield and yield component traits.

\begin{tabular}{|c|c|c|c|c|c|}
\hline Parents & No.F./P. & F.Y./P.kg & F.L.cm & F.D.cm & F.Sh.I. \\
\hline $\mathrm{P}_{1}$ & -0.0340 & 0.1467 & $1.0904^{\star *}$ & $-2.5113^{\star *}$ & $0.0557^{\star *}$ \\
\hline $\mathrm{P}_{2}$ & -0.6040 & 0.5853 & $-2.1649^{\star *}$ & $6.6637^{\star *}$ & $-0.1179^{*}$ \\
\hline $\mathrm{P}_{3}$ & 0.6527 & -0.4113 & $0.2704^{*}$ & $-1.7913^{\star *}$ & $0.0171^{\star *}$ \\
\hline $\mathrm{P}_{4}$ & 0.7560 & -2.2553 & $0.8157^{\star *}$ & $-3.3797^{* *}$ & $0.0601^{\star *}$ \\
\hline $\mathrm{P}_{5}$ & -0.7707 & 1.9347 & -0.0116 & 1.0187 & $-0.0149^{* *}$ \\
\hline L.S.D.0.05 & $\mathbf{0 . 3 5 2}$ & $\mathbf{2 . 6 6}$ & $\mathbf{0 . 2 7}$ & $\mathbf{1 . 2 0}$ & $\mathbf{0 . 0 1 1}$ \\
\hline L.S.D 0.01 & $\mathbf{0 . 4 6 9}$ & $\mathbf{3 . 5 5}$ & $\mathbf{0 . 3 6}$ & $\mathbf{1 . 6 1}$ & $\mathbf{0 . 0 1 4}$ \\
\hline
\end{tabular}

*and ${ }^{* *}$ Significant at 0.05 and 0.01 levels of probability, respectively 
Abd El-Hadi, A. H. et al.

Table 8: Specific combining ability effects (sij) of the $20 F_{1,1 r}$ hybrids for yield and yield component traits.

\begin{tabular}{|c|c|c|c|c|c|}
\hline Hybrids & No.F./P & F.Y./P.Kg & F.L.cm & F.D.cm & F.Sh.I \\
\hline$P_{1} \times P_{2}$ & -0.539 & $6.199^{*}$ & $1.569^{\star \star}$ & $-5.475^{\star \star}$ & $0.063^{\star \star}$ \\
\hline$P_{2} \times P_{1}$ & -0.533 & $6.653^{*}$ & $0.792^{*}$ & -2.025 & $0.075^{\star \star}$ \\
\hline$P_{1} \times P_{3}$ & 0.204 & -3.288 & -0.236 & 0.905 & -0.004 \\
\hline$P_{3} \times P_{1}$ & -2.500 & -1.223 & $-0.655^{\star}$ & -0.150 & 0.010 \\
\hline $\mathbf{P}_{1} \times \mathbf{P}_{4}$ & 0.340 & -0.054 & -0.333 & 2.085 & -0.017 \\
\hline$P_{4} \times P_{1}$ & 0.900 & $-8.413^{*}$ & $-1.463^{\star \star}$ & 1.025 & $-0.047^{\star \star}$ \\
\hline$P_{1} \times P_{5}$ & 0.644 & -1.084 & -0.539 & 1.161 & $-0.023^{*}$ \\
\hline$P_{5} \times P_{1}$ & 0.817 & 4.457 & -1.263 & 0.633 & $-0.038^{*}$ \\
\hline$P_{2} \times P_{3}$ & 0.857 & 5.360 & -0.487 & $2.763^{*}$ & $-0.030^{*}$ \\
\hline$P_{3} \times P_{2}$ & -2.283 & 5.347 & -0.175 & $-4.917^{* *}$ & $0.0367^{*}$ \\
\hline$P_{2} \times P_{4}$ & 1.137 & -4.366 & $-0.614^{*}$ & 2.151 & $-0.031^{*}$ \\
\hline$P_{4} \times P_{2}$ & -0.533 & 0.677 & $-0.717^{*}$ & 1.210 & $-0.041^{\star \star}$ \\
\hline$P_{2} \times P_{5}$ & 0.481 & 3.274 & -0.430 & -0.699 & -0.009 \\
\hline$P_{5} \times P_{2}$ & -0.017 & 3.747 & -0.500 & $4.100^{* *}$ & $-0.035^{*}$ \\
\hline$P_{3} \times P_{4}$ & 0.097 & 2.191 & -0.106 & $-3.460^{*}$ & -0.001 \\
\hline $\mathbf{P}_{4} \times \mathbf{P}_{3}$ & 0.017 & -2.300 & $0.830^{*}$ & $4.567^{* *}$ & $0.033^{*}$ \\
\hline$P_{3} \times P_{5}$ & 1.691 & -0.456 & 0.494 & -0.459 & $0.020^{*}$ \\
\hline$P_{5} \times P_{3}$ & 0.350 & 0.540 & 0.250 & $-2.667^{*}$ & $0.040^{\star \star}$ \\
\hline$P_{5} \times P_{4}$ & 0.687 & 2.375 & -0.464 & -1.104 & -0.009 \\
\hline$P_{4} \times P_{5}$ & 0.917 & -3.517 & $0.987^{* *}$ & 0.667 & $0.023^{*}$ \\
\hline L.S.D(sij) $)_{0.05}$ & 0.726 & 5.49 & 0.55 & 2.48 & 0.02 \\
\hline L.S.D(sij) $)_{0.01}$ & 0.968 & 7.31 & 0.74 & 3.31 & 0.03 \\
\hline L.S.D(rij) $)_{0.05}$ & 0.881 & 6.65 & 0.67 & 3.01 & 0.03 \\
\hline L.S.D(rij) $)_{0.01}$ & 1.174 & 8.87 & 0.89 & 4.01 & 0.04 \\
\hline
\end{tabular}

*and ${ }^{* *}$ Significant at 0.05 and 0.01 levels of probability, respectively.

\section{REFERENCES}

Abd El-Hadi A. H. ; A. M. El-Adl ; M. S. Hamada and M. A. Abdein (2005). Manifestation of heterosis and genetic parameters and earliness traits in squash .J. Agric. Sci., Mansoura Univ., Egypt, 30 (3): 1363 -1379.

Abd El-Hadi A. H. ; M. M. Zaghloul and A. H. Gabr (2004).

Nature of gene action; heterosis and inbreeding depression of yield and yield components traits in squash (Cucurbita pepo, L.). Zagazig J. Agric, Res., 31(6): 2707-2725.

Abd El-Hadi A. H. ; Z. A. Kosba ; Z. M. El-Diasty ; E. H. Askar and G.M. Shamloul (2001). Evaluation of $F_{1}$ hybrids among new selected inbred lines of sweet melon (Cucumis melo var. aegyptiacus, L.).J. Agric. Sci., Mansoura Univ., 26(5): 2831-2845.

Abd El-Salam M. M. ; I. S. El-Demardash and A. H. Hussein (2010). Phenotypic stability analysis; heritability and protein patterns of snake cucumber genotypes. Journal of American Science. 6(12): 503-507.

Ahmed E. A. ; H. S. Ibn Oaf and A. E. El Jack (2003). Combining ability and heterosis in Line $\mathrm{x}$ Tester crosses of summer 
squash (Cucurbita pepo, L.). Cucurbit Genetics Cooperative Report, 26: 54-56.

Ana, I. Lopez-Sese and J. E.Staub (2002). Combining abilityanalysis of yield components in cucumber.J .Amer. Soc. Hort. Sci. 127(6): 931-937.

El-Mighawry A. ; M. M. Abd El-salam and R. A. El-Shabraway (2001). The heritability coefficient and response to selection for heterosis in muskmelon (Cucumis melo, L.) J. Agric. Sci. Mansoura Univ. Egypt, 26 (9): 5517-5526.

El-Shimi A. S. ; S. A. Mohamedein and A. H. M. El-Fouly (2003). Inheritance of some economic traits in melon (Cucumis melo, L.). J. Agric. Sci. Mansoura Univ.Egypt, 28 (6): 4907-4918.

Firpo I. T. ; F. Lopez Anido S. M. ; Garcia and E. Cointry (1998). Heterosis in summer squash (Cucurbita pepo, L.). Cucurbita Genetics Coop., 21: 43-45. (C.F. Pl.Br. Abst., 68(12):13255).

Ghobary H. M. and Kh. Y. Ibrahim (2010). Improvement of summer squash through inbreeding and visual selection. J. Agric. Res. Kafr El-Sheikh Univ.,Egypt. 36( ): 340-349.

Griffing B. (1956). Concept of general and specific combining ability in relation to diallel crossing system Aust. J. Biol. Sci., 90: 463-492.

Hatem, A. K. ; Afaf A. M. ; Salim and I. Z. El-Shimi (2009). Studies on combining ability and correlation in melon (Cucumis melo, L.). Minufia J. Agric. Res., 34 (1): 191-203.

Jahan T. A. ; Islam A. K. ; Rasul M. G. ; Mian M. A. and M. M. Haque (2012). Heterosis of qualitative and quantitative characters in sweet gourd (Cucurbita moschata Duch.ex Poir) 1Department of Genetics and Plant Breeding, Bangabandhu Sheikh Mujibur Rahman Agricultural University, Gazipur 1706, Bangladesh, 12(3): 6186-6199.

Kamooh A. A. (2002). Studies on general and specific combining abilities of some characters in squash (Cucurbita pepo, L.).J. Agric. Sci. Mansoura Univ. Egypt, 27(7): 9861-9888.

Karuppaiah P. ; R. Kavitha and P. Senthilkumar (2002). Studies on variability, heritability and genetic advance in ridge gourd. Indian J. Hort. 59(3): 307-312.

Kasrawi M. A. (1994). Heterosis and reciprocal differences of quantitative traits in summer squash (Cucurbita pepo, L.).J. Gen. Plant Breed., 48(4): 399-403. [C. F. Pl. Br. Abst., 65(6):6401].

Kumar, R. and Wehner, T. (2011). Inheritance of fruit yield in two watermelon populations in North Carolina Euphytica; Vol. 182 Issue 2, p275.

Li-Jian-Wu J. E ; L. J. Liou and Z. Dewwi (1995). Genetic analysis for major agronomic characters in cucumber (Cucumis sativus, L.). International symposium on cultivar improvement of horticultural Crops. Part.1: Veg. Crops, Held at Beiging China on September, 6-10 1993. Acta Hort., No. 402: 388-391.

Lopez-Anido F. ; I. T. Firpo ; S. M. Garcia and E. Cointry (1998). Combining ability in summer squash (Cucurbita pepo L.). Cucurbita Genetics Coop., 21: 40-42.

Mohanty B. K. (2000). Combining ability for yield and its components in pumpkin. Indian J. Genel., 60(3): 373-379. 
Sadek Mariam S. S. (2003). Inheritance of some economical traits in squash (Cucurbita pepo, L.).M. Sc. Thesis, Fac . of Agric ., Mansoura Univ, Egypt.

Shamil Y. Hassan Al-Hamadany and Wiam Y. Rasheed Al- Shakarchy (2011). Analysis of combining ability by full diallel crossing in summer squash (Cucurbita pepo, L.). College of Agric. and Forestry, Mosul University Mosul, Iraq.

El-Diasty, Z.M. ; Kosba, Z.A. ; Abd El-Hadi, A.H. ; Asker, E.H. and Shamloul G. M. (2002). Evaluated of selected inbred lines of sweet melon (Ismailawy) and hybrids among them . Ph. D. Thesis, Fac. of Agric., Mansoura Univ, Egypt.

Souza F. F. ; Queiroz Manoel A. and Dias R. C. S. (2005) Heterotic effects in triploid watermelon hybrids. Crop Breeding and Applied Biotechnology 5: 280-286.

Steel G. D. and H. Torrie (1960). Principles and procedures of statistics. Mc. raw. Hill Book Company, INC, New York, PP. 431.

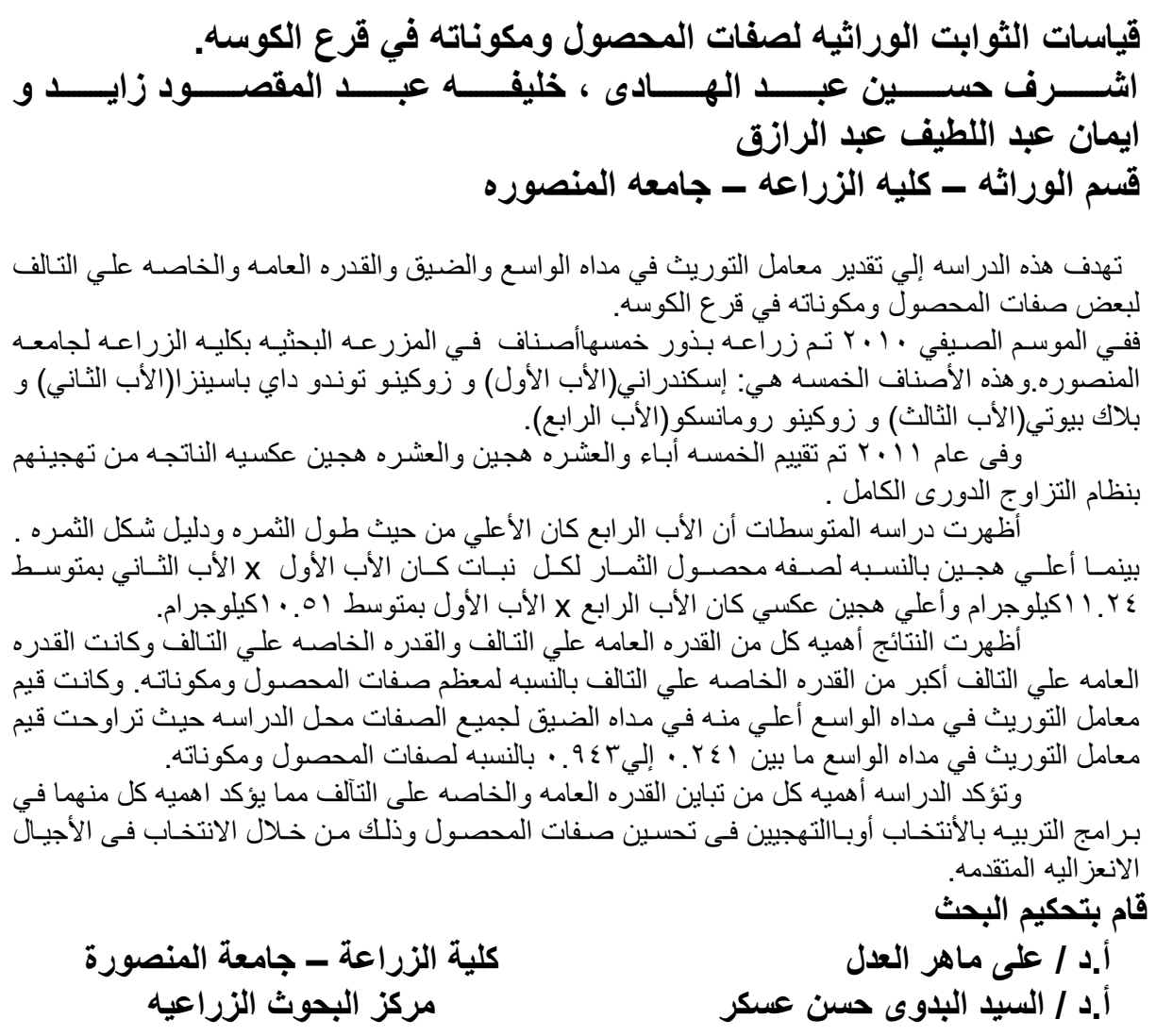


J.Agric.Chem.and Biotechn., Mansoura Univ.Vol. 4 (8), August, 2013 